\title{
12. ARTISTIC EDUCATION/ EDUCATION THROUGH ART IN CONTEMPORARY SCHOOL FROM A TRANSDISCIPLINARY PERSPECTIVE
}

Marina Cosumov ${ }^{279}$

\begin{abstract}
Pupils are interested in concrete problems they are faced with in everyday life and looking explanations and practical solutions to these problems. To identify issues related to the transdiciplinary dimension of music education we shall investigate the concepts of disciplinary, multidisciplinary, interdisciplinary, these being the four arrows of a single bow: the bow of knowledge.
\end{abstract}

Key words: transdisciplinary, lifelong education, transdisciplinary skills, musical education

\section{Introduction}

Musical education, under all its components, represents a continuous individual process of spiritual self-accomplishment of personality through multiple forms of contact with the art of music, as a way to reflect the universe through resonant/ auditory images, of which the individual is a constitutive element. In this context, we notice the integrated approach of the curriculum for this particular subject, typical for transdiciplinarity, which focuses on "real life", important, significant problems as they appear in everyday context and as they affect the lives of people, comprising:

* Musical experience as the essence of the musical act;

* Musical culture as the end of musical education;

* The thematic principle in conceiving the curriculum;

* The musical education lesson as a form of musical-pedagogical activity (creation), imagined as the basis of the principles of artistic dramaturgy;

* The system of students' musical-didactic activities as product derived from the four forms of musical activity: creation-interpretation-audition-analysis;

Musical culture which incorporates the role, functions and ends of culture in general, in the process of which the student, knowing/ valorizing the world, knows/ builds himself as a spiritual being;

* Musical education per se as musicality of the human being by cultivating specific qualities: musical feeling = particular sense of music, musical thinking = judgment in sonorities/ experiences, musical consciousness = capacity to hear the world artistically acoustically, musical intelligence $=$ superior level of musical culture;

Education through music, together with cultivating the general skills of the student (emotiveness, imagination, creative thinking, moral experiences, etc.), aims for the spiritual development - the outmost level of any type of education.

It is known that arts have a great role in the dynamics of the child's life, in getting the child free from complexes and isolation, in getting the child's

\footnotetext{
279 Associate Professor PhD., „Alecu Russo” State University from Bălţi, Republic of Moldavia, email: cosumov@mail.ru
} 
creativity, imagination, sensitivity going, in the development of the physical and psychological processes necessary for the various types of activities by which requalification and adapting to the new requirements of modern life can be obtained. In order for the arts to perform these functions, an efficient pedagogical approach is necessary, including adequate teaching technologies, a co-operation of the arts and sciences, a crossing of the contents both horizontally and vertically, directing them to everyday situations. In this way, a balanced personality is formed, with an increased level of learning autonomy, able to identify and use information sources, to participate in the education of the other members of the collectivity they are part of, in order to increase life quality and the development of society.

The years in school are meant teach students how to learn and how to become socially-culturally integrated. The focus is the implementation of active -participative methods, efficient learning techniques and the development of the self-training capacity into the educational process.

School potentiates and develops the adaptability of students, their capacity to understand on the level of knowledge and culture, an objective C. Cucoş describes as follows: „to know how to use what you know in order to behave intelligently, to give your existence a direction which will never be regretted. The conditions of modern life are those that every human being learns, must learn every day; school is the place where this learning starts, and the skill the child acquires here must offer him what is necessary for him to be able to work alone in the future to perfect himself: education and the educational system are an initiation, a gateway ...” [1].

Unidisciplinarity - teaching particular, concrete notions in the field of music. This method must be approached in such a way so that to allow the child's intelligence to reach broader horizons by linking the stored information with his life experience. However, unidisciplinarity, no matter how necessary it may seem in some moments of the music teaching process, should not remain the most popular method.

Pluridisciplinarity implies the co-operation of two or more disciplines/arts on the same hierarchical level. With the music lesson, this method will applied as a relative juxtaposition of information and materials in order to reach common, complex objectives:

o The relation between music and physics, when the properties of the sound and its effects on the human psychic are discussed;

o The relation between music and nature, when nature has a descriptive character giving rise to associations with nature, phenomena and sounds in nature and everyday life;

o The relation between music and history, when students find out about cultural epochs, historical events, reflected into music;

o The relation between music and philosophy, when music opens philosophical horizons and visions (the music of J. Bach, D. Șostakovici, G. Enescu);

o The relation between music and architecture, when the ideas of form, symmetry and balance, musical development are developed, etc. 
Interdisciplinarity, in the musical field, implies a superior co-operation of two or more domains by which a common content can be achieved, such as musical literature; with the creation of a new musical genre - when the symbiosis music literature appeared; with the apparition of a new art, such choreography, a result of the music-dance synchronism; with the opera, where all arts came together: music, literature, choreography, visual arts, etc.

Transdisciplinarity - means a "stroll" among the arts and sciences both horizontally and vertically, it is a multilevel coordination of disciplines and even of the contents of education in its diversity in order to realise objectives and a common goal. In order to realise the objectives of the Musical education curriculum, transdiciplinarity would become a reality by the realisation of a paradigmatic synthesis of the arts and sciences studied at school.

Transdisciplinarity, although examined in correlation with other notions regarding the organisation of contents into subjects or the specificity of the established links, does differ from these, as seen in the figure below (Figure 1):

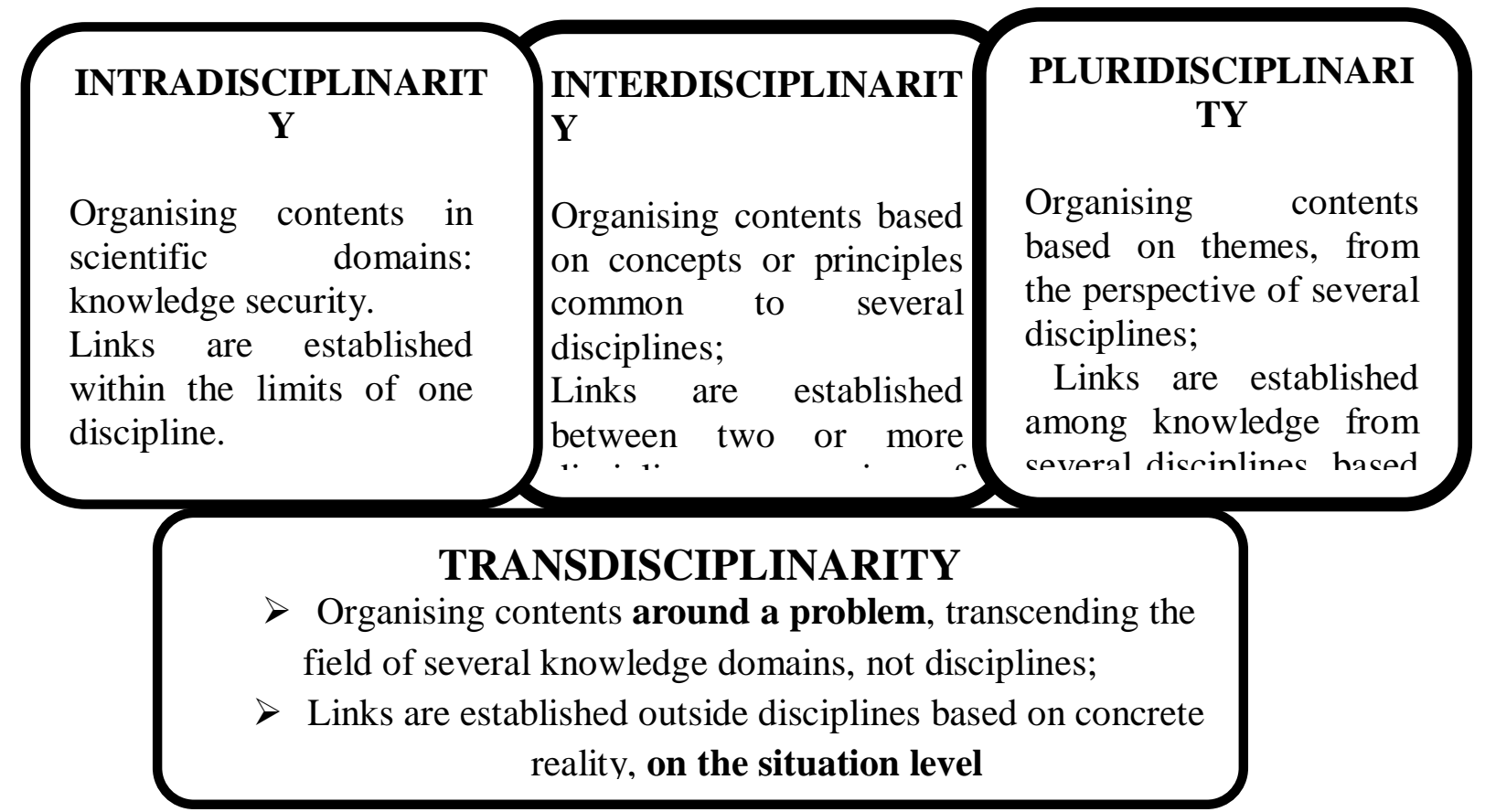

Figure 1. Organising contents on domains

In this perspective, organising content is done vertically intradisciplinarity; horizontally - interdisciplinarity; transversally pluridisciplinarity; extraversally - transdisciplinarity. By P. Popescu, musical self-education (through music) is a conscious activity, aiming at perfecting one's own personality, determined by the level of general cultural education in a social-cultural environment. Musical self-education/ self-education through music is possible due to the three functions of self-awareness:

- anticipative function - projection of our own personality on the background on a high musical and spiritual culture;

- normative function - it becomes obvious in the way we select/ appreciate musical values based on an elevated aesthetic taste; 
- student's competitiveness to reflect himself, by being aware of what he is and what he wants to become by the continuous self-education of musical culture [6].

Researcher R. Gagne, compiling the theories of several authors problematized teaching (I.Lerner, 1965; A. Mahmutov, 1972), programmed teaching (V. Andreev, 1981; N.Talîzina, 1975), solving creative tasks (T.Cudreavţev, 1976; A.Matiuşkin, 1973) etc., comes up with a typology of learning, mentioning that ,each of them requires the existence of an assembly of conditions" [53, p. 125]. Thus, all learning types are influenced by the conditions of learning, some situations when learning is realised and then a "behaviour change" [2] produces.

The transdisciplinary approach places the individual learning processes of students, their needs, interests and characteristics in the centre of the learning experiences. There is an empowering of the students in relation to their own learning by direct participation in all the stages of the process and by structuring education around the great problems and challenges of the contemporary world. The integral personal development and social responsibility of the students are the superordinate goals of learning rendering the disciplines as curricular structures irrelevant. From this standpoint, musical education as a school discipline is studied just like any other phenomenon - physical, linguistic, biological, etc., musical art being above all a means of education and musical knowledge allowing the realisation of the premises for the understanding, reception and integration of music into life.

The laws of musical art are expressed in general themes by which students will become aware that:

- music is an acoustic art acting on the emotional state of the receiver/ interpreter, and the experience of the musical message is the initial point of the knowledge trail, without which all acquired knowledge and developed/ trained skills lose any value;

- music is an imagistic and temporal art, its contents being unveiled in time, gradually, sound by sound; the image of the musical creation is recreated by the receiver based on a re-enactment of the acoustic artistic message;

- music has a specific language of expression, which can be explained and discovered through the four qualities of the musical sound (height, duration, intensity, tone);

- the message of musical creations is inspired from life (nature, society life, experiences, human life); by their message, musical creations can accompany/ describe/ influence/ change life.

Regardless of the level of integration of one learning experience or another, regardless of being included in one category or the other, the integrated projection of the curriculum and the organization as such of the learning process focus on the principle of learning by research/investigation and by discovery, a principle based on a holistic and constructivist vision on the learner and the surrounding world. 
The knowledge and experience of music are translated in the psychological structure of any student. If with exact sciences a theorem requires to be understood in the same way by all students, but at a different pace, then musical creation aims at building an elevated esthetical musical taste, which is formed individually from sensorial perception to musical thinking. Independence in thinking and action implies the capacity of the student to decipher the expression integrated in the music.

The approach of the musical artistic phenomenon from pluri-, inter-, transdisciplinary perspectives generates an ample and diverse emotional and informational load. The students' musical thinking and sensitivity, which develop by interfering various types reflections on music, improving the perception of artistic messages it transmits, relate to various types of students' musical thinking and perception by a reflection of their own private universe. This implies the study and exploration of complex processes and phenomena so that, by coordinating research and their results, in the end new disciplines are born. Its finality is the understanding of the present world, one of its imperatives being the unity of knowledge.

\section{Bibliography}

1. Cucoş, C., (2014), Educaţia estetică, Editura Polirom, Iaşi.

2. Lazăr, V., (2002), Şcoala la răscruce. Schimbare şi continuitate în Curriculum-ul învăţământului obligatoriu, Ed. Polirom, Iaşi.

3. Mohammed, A. S., (1986), Interdisciplinaritatea şi ştiinţele umane, Ed. Ştiinţifică, Bucureşti.

4. Petrescu, P., s.a. (2007), "Transdisciplinaritatea- o nouă abordare a situaţiilor de învăţare", EDP, R.A. Bucureşti.

5. Tomşa, G., (1999), Orientarea şi dezvoltarea carierei de elev, Viaţa Românească, Bucureşti.

6. UNESCO, Reunion sur la methodologie de la reforme des programes scolaires, Doc. ED. 76/Conf. 640/3. 